pressure on the two faces; and in further elaboration of the theory, he outlines a method of estimating the percentage interference of two contiguous wells in the same strata.

In the concluding portion of the paper he discusses data collected during various hydrological surveys, and points out the influence of surface configuration and stratigraphical sequence on the sub-surface water contours.

The next meeting of the Society will be held on Wednesday, November 7th, 1906.

\title{
OBITUARY. \\ PROFESSOR J. F. BLAKE, M.A., F.G.S.
}

W IтH deep regret we have to record the death of this well-known geologist, which occurred on Saturday, 7th July, in his 67th year, at 35, Harlesden Gardens, N.W.

We shall give some account of his life and writings in our September number.

\section{GEORGE FREDERICK HARRIS, F.G.S.}

We have to announce the loss of another able geologist and contributor to this Journal. Mr. George Frederick Harris, F.G.S., who died on 16th July at his residence, 20, Parchmore Road, Thornton Heath, Surrey, after prolonged illness, was one of the founders of the Malacological Society of London, and served the office of Treasurer for some time; he also contributed several papers to its Proceedings. He was for nearly 20 years Lecturer on Geology at the Birkbeck College.

We shall give a fuller account of Mr. Harris's life and work in the September number.

\section{PERCY EMARY, F.G.S.,}

Honorary Secretary of the Geologists' Association, Assistant Lecturer on Geology to the Birkbeck College.

THE unexpected death of this young and most energetic geologist, who for nine years filled the office of Secretary to the Geologists' Association, took place on May 25th, after only a month's illness, at 20, Turle Road, 'Tollington Park, N.

His work for the Geologists' Association was of the greatest value, and by his early decease be leaves a widow but very inadequately provided for. In recognition of his services to science, a Fund, to be called "The Percy Emary Fund," is being raised by geologists and others for Mrs. Emary's benefit; and Mrs. R. S. Herries, 24, Gloucester Street, Belgrave Road, S.W. (wife of the President of the Geologists' Association), has consented to act as Treasurer and receive subscriptions. Miss Mary C. Foley (51, Elm Park Mansions, Park Walk, Chelsea, S.W.) is acting as Secretary. Cheques and postal orders should be made payable to "The Percy Emary Fund," and crossed "Lloyds' Bank, Belgrave Road Branch." 